日作紀（Jpn. J. Crop Sci.） $73(4) ： 396-401 （ 2004 ）$

\title{
岩手県地方における秋播性コムギ冬期播種栽培の 播種適期と最適播種量
}

\author{
荻内謙吾 $^{*, 1)} \cdot$ 高橋昭喜 $^{2)} \cdot$ 作山一夫 ${ }^{1)}$ \\ (1) 岩手県農業研究センター・ ${ }^{2)}$ 岩手県農業研究センター県北農業研究所)
}

\begin{abstract}
要旨：岩手県におけるコムギ秋播栽培において，水稲などの前作物との秋作業の競合を解消するため，秋播性コムギ を根雪前に播種する冬期播種栽培について検討し，最適な播種期と最適な播種量を明らかにした。秋播性品種「ナン ブコムギ」を用い，2000 年から 2002 年の 10 月上旬から 11 月上旬に播種期を旬ごとに変えて出芽までの日数を調べ たところ，播種後の $0^{\circ} \mathrm{C}$ 以上の積算平均気温が $95 \sim 115^{\circ} \mathrm{C}$ なった時点で出芽した。このため，播種が早くて播種日 から根雪始めまでの積算平均気温が $95^{\circ} \mathrm{C} よ り$ 高いと根雪前や雪中で出芽し，凍上害の危険が高くなった，逆に，12 月上旬から 12 月下旬のように播種が遅く越冬後に出芽する場合では, 出芽個体率が高く, 正常に出穂, 成熟した. このことから，冬期播種栽培の岩手県における播種適期は，根雪前や雪中で出芽することのない 12 月上旬から 12 月 下旬とすることが適当と考えられた。冬期播種栽培は，10月上旬播種の慣行秋播栽培と比較して地上部の生育量は 小さくなるものの，穂数は多く，倒伏が少なく，子実収量は $379 \mathrm{~g} / \mathrm{m}^{2}$ で慣行秋播栽培対比 $95 \%$ なった。冬期播種 栽培で得られた子実の外観品質は慣行秋播栽培とほぼ同等で，子実の粗タンパク質含有率は $14.4 \%$ と.4 ポイント 慣行秋播栽培のものよりも高まった。播種量を増やすと穂数は直線的に増加し，それに伴い子実収量も増加し，350 粒 $/ \mathrm{m}^{2}$ 前後で最大となった。
\end{abstract}

キーワード：秋播性，コムギ，最適播種量，冬期播種，播種適期.

岩手県において，秋播コムギは主要な水田転作作物とし てきわめて重要であるが, 近年の麦の「本作化」に伴い栽 培面積は急増しており, 特に水田での栽培は栽培面積全体 の $85 \%$ を占めるに至っている。岩手県南部におけるコム ギの播種適期は 10 月上中旬であるが，通常の秋播栽培で は播種作業が水稲などの夏作物の収穫作業と競合すること が営農上の課題となっている。特に，この時期は気温が低 下し，降雨があると圑場が乾きにくく，転換畑とりわけ水 稲收穫後は耕起作業が困難なことが多いために排水対策が 不十分となり, 播種作業が遅れがちとなる。このため, 排 水不良による出芽・苗立率の低下や，中途半端な晚播によ る越冬性の低下や凍上害等により生育・収量が不安定にな る事例が多くみられる。通常，秋播コムギは播種時期が遅 くなるほど越冬性が低下し, 茎数不足等から収量は低下す る。播種量の増加や追肥等によりある程度収量低下は抑え られるものの, 岩手県のような長期積雪期間 (以下, 根雪 期間という）がある地帯では晚播限界があるとされてきた (折坂ら 1985).

北海道では, 収量性が低い春播性コムギの増収技術とし て，根雪直前に播種する初冬播栽培が行われており，生産 安定化のため数多くの研究がなされている（吉田ら 1994, 佐藤・沢口 1998, 沢口・佐藤 2001)。この栽培法は春播コ ムギにとっては究極の早播き技術といえるが，岩手県の主 力品種である秋播性の「ナンブコムギ」についても根雪前 の冬期に播種 (以下, 冬期播種とする) する栽培技術 (すな わち究極の遅播き技術）が確立すれば，夏作物との労力競 合が解消され，排水対策や固場準備等麦作へのスムーズな 移行が可能となり, 麦踏みや雪腐病防除等の越冬前作業も
不要になると考えられる。本報告では, この秋播コムギの 冬期播種栽培を安定的な技術とするために, 冬期播種栽培 の出芽特性からみた播種適期, 最適播種量及び収量特性に ついて明らかにした。

\section{材料と方法}

試験は岩手県農業研究センター (岩手県北上市) 内の圃 場（表層腐植質黒ボク土, 普通畑）で, 次に示す試験 1 と 試験 2 の 2 種類の試験を実施した。供試品種は秋播性の「ナ ンブコムギ」で, 栽植様式は条間 $30 \mathrm{~cm}$, 密条播とした。 施肥は以下のとおりとした。すなわち，10月上中旬播種 区は，播種直前に窒素 $(\mathrm{N})$, リン酸 $\left(\mathrm{P}_{2} \mathrm{O}_{5}\right)$, カリ $\left(\mathrm{K}_{2} \mathrm{O}\right)$ をそれぞれ $4.0,13.5,10.0 \mathrm{~g} / \mathrm{m}^{2}$ 基肥として全層施用し, 翌春の 3 月 20 日前後 (根雪期間終了後) と止葉抽出期に窒 素を各 $2 \mathrm{~g} / \mathrm{m}^{2}$ 追肥した。 11 月上旬以降の播種区では基肥 を施用せず，翌春の 3 月 20 日前後にそれぞれ 10.0 , $33.8,25.0 \mathrm{~g} / \mathrm{m}^{2}$ を圃場全面に表面施用し, さらに止葉抽 出期に窒素を $4 \mathrm{~g} / \mathrm{m}^{2}$ 追肥した。種子消毒は, イミノクタジ ン酢酸塩液剤を用いて塗沫処理した。なお，越冬前の雪腐 病対象の殺菌剤散布は全て実施しなかった。試験面積は $14.4 \mathrm{~m}^{2}$ / 区で, 2 反復とした。生育調査の位置は試験区の 対角線方向に 2 箇所 (各 $2 \mathrm{~m}$ ) とし, 収穫調査はそれぞれの 箇所から 3 条分 $\left(3.6 \mathrm{~m}^{2} /\right.$ 区) を刈取りして実施した。

\section{試験 1 ．最適な播種期の検討}

2000 年播種から 2002 年播種の 3 年間にわたり, 播種期 を 10 月上旬から 12 月下旬まで 5〜7 水準を設定した。実 際の播種日は第 1 表に示した。播種量は, 10 月上旬が 155 
粒 $/ \mathrm{m}^{2}, 10$ 月中旬が 215 粒 $/ \mathrm{m}^{2}, 11$ 月上旬以降は穂数を確 保するために播種量を増やし， 350 粒 $/ \mathrm{m}^{2}$ とした。播種期 別に翌春の生存または出芽個体率, 出穂期, 成熟期を調査 し, また成熟期における倒伏程度についても調査した。生 存または出芽個体率の調査は越冬後の新たな出芽がみられ なくなった時期 (4月上旬) に行い, 播種量に対する翌春の 生存個体または出芽した個体の割合で表した。この他, 越 冬直前の葉齢と雪腐病及び根雪前に発生した凍上害 (霜柱 による根の浮き上がり）による被害程度を 4 月下旬に調査 した. また, 播種から出芽までの $0^{\circ} \mathrm{C}$ 以上の積算平均気温 については, 同研究センターの構内にある気象観測装置を 用いて算出した。なお，各年次の根雪期間は，2000 年播種 が 2000 年 12 月 25 日 2001 年 3 月 20 日, 2001 年播種が 2001 年 12 月 15 日〜 2002 年 3 月 1 日, 2002 年播種が 2002 年 12 月 25 日〜 2003 年 3 月 16 日であった。

10 月上旬に播種した慣行の秋播栽培と, 12 月上旬以降 に播種した冬期播種栽培について, 3 力年の成熟期生育量, 収量, 収量構成要素, 子実の外観品質, 子実の粗タンパク 質含有率を調査し, 慣行の秋播栽培と冬期播種栽培の収量 性を比較検討した。なお，子実の粗タンパク質含有率はケ ルダール法により子実全体の窒素濃度を測定し, $13.5 \%$ 水 分換算, タンパク換算係数 5.83 を乗じて算出した.

\section{試験 2 ．最適な播種量の検討}

冬期播種栽培の収量安定化を目的として, 1997 年播種か ら 2001 年播種にかけて播種量と子実収量との関連につい
て調査した。各年次の播種量は, 1997 年播種と 1998 年播 種が 250 粒 $/ \mathrm{m}^{2}, 1999$ 年播種が 150 粒 $/ \mathrm{m}^{2}, 2000$ 年播種が $300,350,400$ 粒 $/ \mathrm{m}^{2}, 2001$ 年播種が $200,250,300,350$, 400， 450 粒 $/ \mathrm{m}^{2}$ とした。播種期は， 1997 年播種が 12 月 16 日，1998 年播種が 12 月 24 日， 1999 年播種が 12 月 27 日, 2000 年播種が 12 月 1 日（播種量 350 粒 $/ \mathrm{m}^{2}$ のみ）と 12 月 20 日，2001 年播種が 12 月 5 日（播種量 350,400 粒 $/ \mathrm{m}^{2}$ の み）と 12 月 21 日とした。

\section{結果}

\section{1. 最適な播種期の検討}

播種期別の出芽期と, 翌春の生存または出芽個体率を第 1 表に, 播種期別の出穂期と成熟期及び倒伏程度を第 2 表 に示した. 11 月上旬までの播種期では根雪前に出芽したが, 11 月中旬播種になると根雪前には出芽せず雪中での出芽 となり，12 月上旬以降の播種では根雪期間終了後に出芽 した。翌春の生存または出芽個体率は, 播種期によらず $80 \%$ 以上となり (第 1 表), 反復間のばらつきもごく僅かで あった。播種期が遅いほど出穂期, 成熟期は遅くなったが, その差は出穂期で最大 6 日, 成熟期で最大 5 日であった。 梅雨時期との関係では, 慣行の播種期を含む全ての播種期 で梅雨入り後の収穫となった。 また, 出芽期, 出穂期, 成 熟期の反復間での差はなかった。 倒伏は 10 月上旬播種で 多く, 11 月上旬播種までは倒伏がみられたが, それ以降 の播種期では各年次とも倒伏はみられなかった (第 2 表). 根雪前に出芽のみられた 10 月上旬から 11 月上旬播種に

第 1 表 試験年の播種期, 出芽期, 翌春の生存または出芽個体率.

\begin{tabular}{|c|c|c|c|c|c|c|c|c|c|}
\hline \multirow[t]{2}{*}{ 播種期 } & \multicolumn{3}{|c|}{ 播種期（月．日） } & \multicolumn{3}{|c|}{ 出芽期（月．日） } & \multicolumn{3}{|c|}{ 翌春の生存または出芽個体率（\%) } \\
\hline & 2000年 & 2001年 & 2002年 & 2000年 & 2001年 & 2002年 & 2000年 & 2001年 & 2002年 \\
\hline 10月上旬 & 10.5 & 10.4 & 10.3 & - & 10.12 & 10.9 & - & 88 & 81 \\
\hline 10月中旬 & - & - & 10.18 & - & - & 10.27 & - & - & 83 \\
\hline 11月上旬 & 11.10 & 11.5 & 11.5 & 12. 19 & 11.24 & 12. 18 & 94 & 83 & 92 \\
\hline 11月中旬 & 11.20 & 11.20 & - & 雪中 & 雪中 & - & 89 & 96 & - \\
\hline 11月下旬 & 11.30 & - & 11.22 & 雪中 & - & 雪中 & 87 & - & 92 \\
\hline 12 月上旬 & - & 12.5 & 12.6 & - & 3.6 & 3. 16 & - & 90 & 90 \\
\hline 12月中旬 & 12. 20 & - & 12.12 & 3. 20 & - & 3. 17 & 87 & - & 97 \\
\hline 12月下旬 & - & 12.21 & 12.24 & - & 3. 13 & 3. 19 & - & 81 & 93 \\
\hline
\end{tabular}

生存または出芽個体率の調查は，2000年から順に播種翌年の4月 9日，4月 2 日，4月 1 日に行い，10月上旬〜 11 月下旬は生存個体率，12月上旬以降は出芽個体率である.

第 2 表 播種期別の出穂期, 成熟期と倒伏程度.

\begin{tabular}{|c|c|c|c|c|c|c|c|c|c|}
\hline \multirow[t]{2}{*}{ 播種期 } & \multicolumn{3}{|c|}{ 出穂期（月。日） } & \multicolumn{3}{|c|}{ 成熟期（月。日） } & \multicolumn{3}{|c|}{ 倒伏程度 } \\
\hline & 2000年 & 2001年 & 2002年 & 2000年 & 2001年 & 2002年 & 2000年 & 2001年 & 2002年 \\
\hline 10月上旬 & 5.14 & 5.9 & 5.14 & 7.1 & 7.3 & 7.2 & 0 & 3.6 & 1.0 \\
\hline 10月中旬 & - & - & 5.17 & - & - & 7.2 & - & - & 0 \\
\hline 11月上旬 & 5.15 & 5.12 & 5.20 & 7.6 & 7.5 & 7. 4 & 0 & 3.6 & 0 \\
\hline 11月中旬 & 5.15 & 5.12 & - & 7. 7 & 7.5 & - & 0 & 0 & - \\
\hline 11月下旬 & 5.16 & - & 5.19 & 7.8 & - & 7.4 & 0 & 0 & 0 \\
\hline 12 月上旬 & - & 5.13 & 5. 18 & - & 7.7 & 7.5 & - & 0 & 0 \\
\hline 12 月中旬 & 5.16 & - & 5.20 & 7.8 & - & 7.5 & 0 & 0 & 0 \\
\hline 12月下旬 & - & 5.14 & 5.20 & - & 7.8 & 7.6 & - & 0 & 0 \\
\hline
\end{tabular}

倒伏程度は成熟期における倒伏で, 無 : 0, 微 : 1, 少 : 2, 中 : 3, 多 : 4, 甚 : 5とした. 各年の 梅雨入り（梅雨明け）は，2000年から順に播種翌年の6月6日（特定せず），6月11日（7月25日）， 6月12日（特定せず）であった. 
ついて，播種から出芽までの $0^{\circ} \mathrm{C}$ 以上の積算平均気温と出 芽まで日数の関係をみると(第 1 図), 播種期が遅いほど出 芽までに要する日数は長くなるが, 出芽に要する $0^{\circ} \mathrm{C}$ 以上 の積算平均気温は $95 \sim 115^{\circ} \mathrm{C}$ 範囲にあった。

第 3 表には, 2002 年播種の播種期別の雪腐病および凍上 害の発生程度を示した。11月上旬播種までの試験区が根 雪前に出芽したが, ぞの播種期も雪腐病の発生は認められ ず，また翌春の生存または出芽個体率も $80 \%$ 以上 (第 1 表) であった。凍上害による枯死株は，10月中旬播種ではほ とんど認められなかったが, 11 月上旬播種では多かった. 根雪前に出芽しなかった 11 月下旬以降の播種では, 10 月 中旬播種と同様に枯死株が少なかった。 また，他の試験年 においても，2002 年と同様に播種期によらず雪腐病の発生 は認められなかった。

冬期播種栽培と慣行の秋播栽培の生育・収量特性を第 4 表に示した。成熟期の生育量は, 慣行の秋播に比べて㷏長

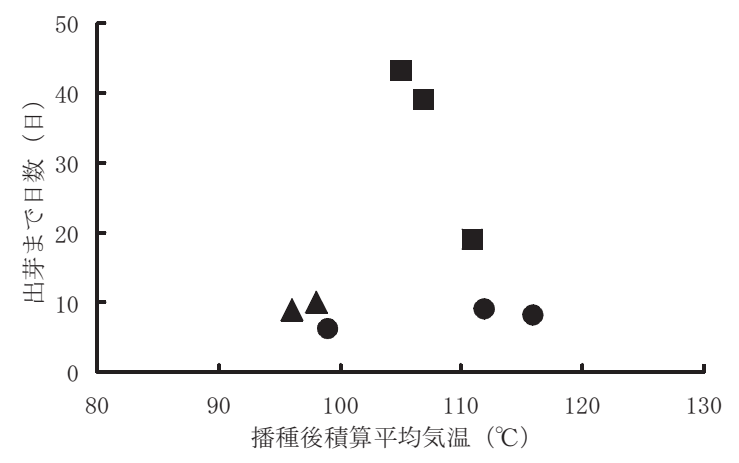

第 1 図 播種後積算平均気温と出芽まで日数の関係.

平均気温は $0^{\circ} \mathrm{C}$ 以上を積算した。: 10 月上旬播種,

$\boldsymbol{\Delta}$ : 10月中旬播種, $\boldsymbol{\square}: 11$ 月上旬播種.

第 3 表 雪腐病と凍上害発生程度の比較 (2002年播種).

\begin{tabular}{|c|c|c|c|}
\hline $\begin{array}{l}\text { 調査日 } \\
\text { 播種期 }\end{array}$ & $\begin{array}{c}\text { 12月 } 24 \text { 日 } \\
\text { 葉齢 } \\
\text { (葉) }\end{array}$ & $\begin{array}{l}3 \text { 月 } 25 \text { 日 } \\
\text { 雪腐病 } \\
\text { の有無 }\end{array}$ & $\begin{array}{c}\text { 4月 } 28 \text { 日 } \\
\text { 枯死株率 } \\
(\%)\end{array}$ \\
\hline 10月中旬 & 3.0 & $\begin{array}{l}\text { 無 } \\
\end{array}$ & 0.1 \\
\hline 11月上旬 & 1.0 & 無 & 5.1 \\
\hline 11月下旬 & - & 無 & 0.4 \\
\hline 12月上旬 & - & 無 & 0 \\
\hline
\end{tabular}

葉齢以外は播種翌年のデータである.
と穂長が短く, 一穂粒数も少なく有意な差がみられた。千 粒重は慣行の秋播よりも小さいものの, 有意差はなかっ た。一方, 最高分げつ期の分げつ数は株あたり 0.7 本と慣 行の秋播よりも少なかったが, 有効茥歩合が $98 \%$ と高く, 穂数は慣行の秋播を上回った。 また, 子実収量も $379 \mathrm{~g}$ $/ \mathrm{m}^{2}$ となり, 慣行の秋播対比で $95 \%$ と有意な差はみられな かった。品質面をみると，外観品質は冬期播種で僅かに劣 る傾向がみられたものの, 検査等級は同等であった。 子実 の粗タンパク質含有率は有意差はないものの, 冬期播種が $14.4 \%$ と高く, 慣行の秋播を 1.4 ポイント上回った.

\section{2. 最適な播種量の検討}

1997 年〜2001 年に, 12 月上旬〜下旬に播種した場合に おける播種量と出芽個体数及び収量関連形質との関係を第 2 図に示した。出芽個体率は年次によってやや異なり, 2001 年 12 月 5 日および 12 月 21 日播種の播種量 400 粒 $/ \mathrm{m}^{2}$ ではそれぞれ $71 \%$ \% $78 \%$ のやや低い值を示したが，こ の他の年次あるいは播種期ではいずれの播種量でも $80 \%$ 以上の值を示した. このため, 出芽個体数は播種量の増加 とともに有意に増加した。播種量と穂数にも高い相関関係 がみられ, 播種量を増やすと穂数は直線的に増加した。穂 長は播種量の増加とともに短くなる傾向があり，また一穂 粒数は播種量との間に一定の傾向がみられなかったが, 350 粒 $/ \mathrm{m}^{2}$ を越えると少なくなる傾向がみられた。千粒重 に関しては, 播種量との間に一定の傾向はみられなかった。 子実収量は, 播種量と有意な正の相関関係があり, 播種量 の増加とともに子実収量も大きく増加した。しかし, 播種 量 350 粒 $/ \mathrm{m}^{2}$ 以上では増加が緩やかとなる傾向であった.

\section{考察}

播種期を段階的に変えた試験 1 では，供試した全ての播 種期において翌春の生存または出芽個体率が $80 \%$ 以上と なり，根雪前に出芽しない 12 月の播種でも積雪下で越冬 し, 正常に出芽した (第 1 表)。コムギの耐寒性は肧乳消尽 期である 2〜3 葉期頃に最も低下し，それより小さい時期 に積雪下となった場合には種子中の養分を利用して越冬す ることが知られているが（㴰島 1943, 黒崎 1951, 吉田ら 1994)，耐寒雪性が「強」に分類される「ナンブコムギ」

第 4 表 冬期播種栽培と慣行秋播栽培の生育及び収量構成要素の比較 (2000～2002年播種平均).

\begin{tabular}{|c|c|c|c|c|c|c|c|c|c|c|c|}
\hline 栽培法 & $\begin{array}{c}\text { 最高 } \\
\text { 分げつ数 } \\
\text { (本/個体) }\end{array}$ & $\begin{array}{l}\text { 秙長 } \\
(\mathrm{cm})\end{array}$ & $\begin{array}{l}\text { 穂長 } \\
(\mathrm{cm})\end{array}$ & $\begin{array}{l}\text { 穂数 } \\
\left(\text { 本 } / \mathrm{m}^{2}\right)\end{array}$ & $\begin{array}{l}\text { 有効茥 } \\
\text { 歩合 } \\
(\%)\end{array}$ & $\begin{array}{l}\text { 一穂 } \\
\text { 粒数 } \\
(\text { 粒) }\end{array}$ & $\begin{array}{c}\text { 千粒重 } \\
(\mathrm{g})\end{array}$ & $\begin{array}{c}\text { 子実収量 } \\
\left(\mathrm{g} / \mathrm{m}^{2}\right)\end{array}$ & $\begin{array}{l}\text { 秋播 } \\
\text { 対比 } \\
(\%)\end{array}$ & $\begin{array}{c}\text { 子実 } \\
\text { タンパク } \\
(\%)\end{array}$ & $\begin{array}{l}\text { 外観 } \\
\text { 品質 }\end{array}$ \\
\hline 冬期播種 & 0.7 & 71 & 7.6 & 518 & 98 & 19.9 & 41.2 & 379 & 95 & 14.4 & $3.7(1.7)$ \\
\hline 慣行秋播 & 6.4 & 92 & 9.9 & 341 & 37 & 29.8 & 44.2 & 400 & 100 & 13.0 & $3.3(1.7)$ \\
\hline 有意差 & * & ** & * & ns & $* *$ & $*$ & ns & ns & ns & ns & ns \\
\hline
\end{tabular}

冬期播種は 12 月上旬〜下旬に播種した試験区の平均值. 慣行秋播は 10 月上旬播種. 有意差検定は年次を反復とし て実施した (対応のある $\mathrm{t}$ 検定)。*は5\%水準で，**は1\%水準で有意差があることを示す．外観品質は，上上：1， 上下 : 2 , 中上 : 3 , 中中 : 4, 中下 : 5 , 下 : 6 の 6 段階で評価. ( ) 内の数值は岩手農政事務所調べによる検査 等級. 

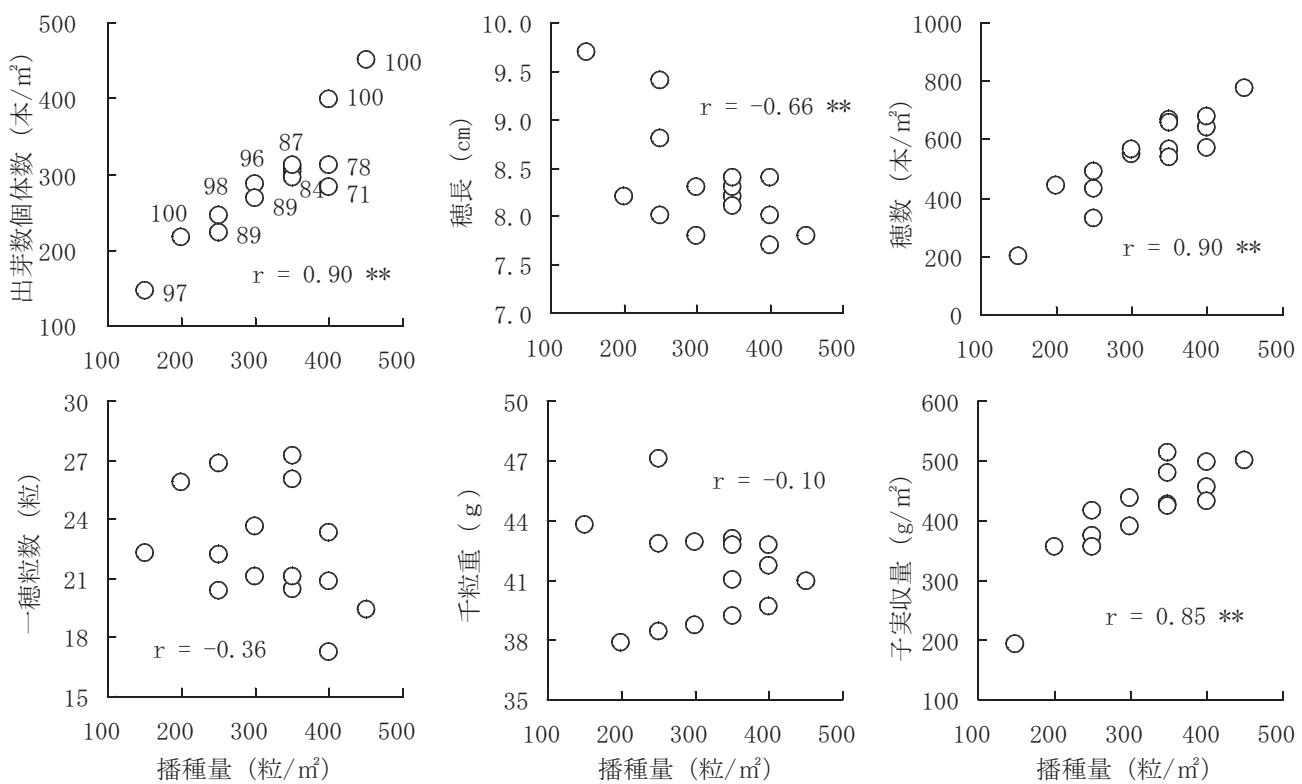

第 2 図 播種量と出芽個体数及び収量関連形質の関係.

左上の図中の数值は出芽個体率 $(\%)$ を示す，**は $1 \%$ 水準で有意であることを示す.

については, 越冬前の葉歯によらず越冬性が高いことが明 らかとなった。また，12月播種では越冬後の出芽個体に 雪腐病の発病は認められなかった。一方，秋播栽培では, 霜柱による凍上害（根上がりによる物理的障害）が根雪前 にしばしばみられ，晚播栽培では収量性低下の要因とも なっている（山田・田村 1952，仁木 1963)。本試験の結果 から，播種から出芽までには $0^{\circ} \mathrm{C}$ 以上の積算平均気温で 95 $\sim 115^{\circ} \mathrm{C}$ を要したが (第 1 図), 根雪前に出芽した 11 月上旬 播種では，正常に越冬したにもかかわらず凍上害による枯 死株率が高かった (第 3 表)。これは越冬直前の葉齢が 1.0 葉と小さく，十分な根張りが確保されなかったために凍上 害が起きたためと考えられるが，11月下旬以降の播種で は根雪前に出芽せず雪中または越冬後に出芽し, 出芽後も 凍上害の発生がみられなかった。11月上旬播種の被害程 度は枯死株率が $5.1 \%$ であり，数值的には穂数に与える影 響は必ずしも大きくはなかったが，岩手県のように頻繁に 霜柱が発生する地域では根雪前に出芽することの不安定性 を示す結果といえる。したがって，安定的な苗立ちを確保 するためには，播種期は根雪前に出芽しない時期，すなわ ち例年の根雪始め (岩手県では 12 月下旬) からさかのぼっ て $0^{\circ} \mathrm{C}$ 以上の積算平均気温が $95^{\circ} \mathrm{C}$ 以下の期間が適当と考元 られる。この境界の時期は岩手県では概ね 11 月下旬であ るが, 根雪始めは年次変動があり予測が困難なことから, より安全な播種期としては 12 月上旬から 12 月下旬が妥当 と考えられる。これによって排水対策の実施にゆとりがで きること，麦踏みや雪腐病防除が省略できること等，作業 面でのメリットは大きいと考えられる。

冬期播種栽培と慣行の秋播栽培の収量特性を比較すると (第 4 表)，程長と穂長は慣行の秋播栽培よりも有意に小さ
く, 収量構成要素も穂数を除いて慣行の秋播栽培を下回っ た。一般に秋播コムギでは晚播により程長，穂長等の生育 量が小さくなり減収する（平野 1981，湯川・渡辺 1997) が，一穂粒数や千粒重には差異はなく, 収量の低下は主と して穂数の減少による（折坂ら 1985）ところが大きい. 本 試験の冬期播種栽培では, 慣行の秋播栽培に比べて播種量 を 2 倍以上に増やすことでこの穂数の低下を補抢うとした ところ，播種量が多いために株あたりの分げつ数は慣行の 秋播栽培の約 9 分の 1 と少なくなったものの, 有効茎歩合 が $90 \%$ 以上と高くなったため, 慣行の秋播栽培との収量差 は 5\%とごく小さいものとなった。桃谷ら（1985）は，「ナ ンブコムギ」を用いた晚播栽培試験で，越冬前の葉齢が 4 葉程度の場合, 越冬前の茎数が多いほど越冬茎率と有効茎 歩合が低下し，慣行の秋播栽培並みの収量 $(400 \mathrm{~kg} / 10 \mathrm{a})$ を 確保するには 480 粒 $/ \mathrm{m}^{2}$ の播種量が必要と報告している. 本試験でこれより少ない 350 粒 $/ \mathrm{m}^{2}$ の播種量で慣行の秋播 栽培並の収量を上げたことは, 根雪前に出芽せずに越冬後 から生育を開始させることの有利性を示すものといえる.

品質面では，外観品質には冬期播種栽培と慣行の秋播栽 培で大差がなく，検査等級でも 1 2 等を確保していた. 折坂ら（1985）の「ナンブコムギ」を用いた試験では，晚 播につれて粒色と粒張りが劣り外観品質が低下すると報告 されており，本試験の結果と異なるが，本試験とは播種量 や施肥量，施肥時期が大きく異なることや播種時期が 11 月下旬とやや早いことから, 分げつ発生量や生育進度に相 違があったためと考えられる。このことから，生育量に対 応した施肥量や施肥時期についての検討が今後必要と考え られるが，3 年間の試験において，少なくとも「赤かび粒」 や「黒かび粒」，および「穂発芽粒」の発生は慣行の秋播 
栽培と差がなかったことから, 成熟期が $3 \sim 7$ 日遅くなっ た (第 2 表) ことによる降雨の品質への影響 (雨害) は小さ かったものと考えられた。子実の粗タンパク質含有率は, 冬期播種が $14.4 \%$ と慣行の秋播栽培よりも高かった が，一般に晚播ほど粗タンパク質含有率が高まる傾向があ り（鈴木ら 1989），本試験もこれと同様な結果といえる. コムギの粗タンパク質含有率については，岩手県内の製粉 会社等の実需者から高タンパク（子実全体で $11 \sim 12 \%$ 以 上）なものが望まれているところであるが，過度の高夕ン パク化は粉色の低下や茹麺の色相や食感の低下を招くこと が多い（佐藤 1991，中津ら 1999）。冬期播種栽培コムギの 加工特性については今後検討を要するが，外観品質を維持 しつつ慣行の秋播栽培に比べて高タンパクとなることは, 低タンパクが問題となる水田転作地域にとっては好ましい 結果といえよう。

最適な播種量について検討した試験 2 の結果（第 2 図） では, 穂数は播種量と高い正の相関関係を示し, 播種量の 増加により穂数が増加し, 子実収量は播種量 350 粒 $/ \mathrm{m}^{2}$ 前 後までは明らかに増加した。下野（1982）は，秋播コムギ の生産性について，111～700 粒 $/ \mathrm{m}^{2}$ の播種量間に収量差は 認められなかったと報告している。また，桐原（1984）は, 苗立本数が 250 本 $/ \mathrm{m}^{2}$ 前後までは収量が増加するが，これ より苗立本数が多くなると収量が低下すると述べている. これは，播種量の増加に伴い穂数は増加するが，反対に一 穂粒数と千粒重が減少するためである。すなわち, 慣行の 秋播栽培では増収を目的に播種量を増加させることには限 度があり, 播種量そのものの収量に対する影響の程度が必 ずしも高くないことを意味する。また，慣行の秋播栽培で は分げつ期間が長いため, 播種量の増加により無効分げつ が増えることも要因となろう（川口 1984）。一方，冬期播 種栽培では分げつ期間が短いため，慣行の秋播栽培に比べ ると分げつ数が少なくなることから，播種量の増加による 穂数の増加，またそれによる子実収量の増加効果が大きい (第 2 図)，沢口・佐藤 (2001) は，春播コムギの初冬播栽 培に打いて，播種量を増やしても増収効果は認められな かったと報告している，その要因として，穂数が増加して も穂長が短くなり千粒重が低下するためとしているが，本 試験の結果では播種量の増加による千粒重の低下はみられ ず，春播コムギとの違いがみられた。とはいえ，密植によ り穂長が短くなり粒数増加は緩やかとなり, 収量増加も慣 行の秋播栽培と同様に限界がみられた。「ナンブコムギ」 の而倒伏性は「弱」であるため，慣行の秋播栽培では倒伏 回避と収量確保の兼ね合いから播種量は 140 粒 $/ \mathrm{m}^{2}$ (播種 重量で約 $6 \mathrm{~kg} / 10 \mathrm{a})$ 程度である。しかし，本試験の冬期播 種ではどの播種量においても倒伏はみられなかったことか
ら，安定的に収量を確保する意味からも播種量は最高収量 が得られる 350 粒 $/ \mathrm{m}^{2}$ が妥当と考元られた。

今後は，秋播性コムギの冬期播種栽培をさらに安定的な 技術とするために, 高品質・多収を維持するための窒素施 肥法や，製粉性・製麺性といった加工特性の解明が必要と 考元られる。

謝辞 : 本報告をまとめるにあたり，貴重なご意見を頂い た農業・生物系特定産業技術研究機構東北農業研究セン ターの小柳敦史室長に深謝いたします。

\section{引用文献}

平野寿助 1981. 新しいムギ栽培。農文協，東京．1-274.

川口數美 1984. ムギ栽培の基礎理論 I 収量構成。農業技術体系作物 編 4 基本技術編追録 第 6 号 : $3-22$.

桐原三好 1984. ムギ栽培の基礎理論III生育のタイプと収量構成。農 業技術体系作物編 4 基本技術編追録 第 6 号 : 37-49.

黒崎正美 1951. 麦作改善の狙い一離乳期の生理を中心として一。農 及園 $26: 849-852$.

桃谷英 - 横尾信彦 - 安藤明子. 阿部吉克 1985 . 山形県における小麦 大豆を中心とした 1 年 2 作体系技術の確立. 東北農業研究 $37: 169$ -170 .

中津智史・渡辺祐志 ・ 奥村理 1999. 窒素施肥および収穫前の降雨が 小麦品質に及ぼす影響. 土肥誌 $70: 514-520$.

仁木䉷雄 1963. 霜柱水層による作物の被害ならびにその防除に関す る研究。農事試研報 $3: 125-168$.

折坂光臣・高橋康利・清原悦郎 1985. 岩手県に拧ける小麦・大豆を 基幹とする新体系化技術化関する研究. 東北農業研究 $37: 163-$ 164.

佐藤暁子 1991. 小麦の蛋白質含量安定化技術の開発．農及園 $66: 7-$ 14.

佐藤導謙・沢口敦史 1998. 北海道中央部における春播コムギの初冬 播栽培に関する研究一播種期と越冬性について一. 日作紀 $67: 462$ -466 .

沢口敦史・佐藤導謙 2001. 北海道中央部に打ける春播コムギの初冬 播栽培に関する研究一適正播種量について一。 日作紀 $70: 505-$ 509.

下野勝昭 1982. 秋播小麦の生産性，北海道立農業試験場資料 $15: 146$ -155 .

鈴木武 - 原田康信 ・斎藤敏一 ・ 阿部吉克 - 斎藤博行 1989. 小麦のア ミログラム (最高粘度) 低下要因。山形農試研報 $24: 1-11$.

瀧島英策 1943 . 小麦の耐雪性に関する研究 第 2 報根雪前に於ける発 芽相の差異と耐雪力。農及園 $18: 922-926$.

山田忍・田村昇市 1952. 火山性土の凍結並融凍作用が土袞と作物に 及ぼす影響とこれが対策に関する研究 (第 2 報)。土肥誌 $23: 101$ $-104$.

吉田みぞり・阿部二朗・森山真久・高屋武彦 1994. 初冬播きした春 播コムギの越冬性及び低温発芽機構。北農試研報 $159: 59-66$.

湯川智行・渡辺好昭 1997. 北陸地域におけるオオムギ，コムギの極 晚播栽培. 日作紀 $66: 501-502$. 
Optimum Seeding Date and Seeding Density for Winter-Seeding Cultivation of Winter Wheat in Iwate: Kengo OGIUCHI $\left.{ }^{*}, 1\right)$, Akiyoshi TAKAHASHI ${ }^{2}$, Kazuo SaKuyama ${ }^{1)}\left({ }^{1)}\right.$ Iwate Agricultural Research Center, Kitakami 024-0003, Japan; ${ }^{2)}$ Iwate Agricultural Research Center, Kenpoku Agricultural Institute)

Abstract : Winter wheat, usually seeded in autumn, was seeded before continuous snow cover to avoid the overlap between work for wheat sowing and rice harvesting. Then, the optimum seeding date and seeding density were determined. Winter wheat cultivar "Nanbukomugi" was seeded at intervals from early October to late November in 2000 2002. The seedlings emerged when accumulative mean temperature above $0{ }^{\circ} \mathrm{C}$ after seeding reached $95 \sim 115{ }^{\circ} \mathrm{C}$. When the seeding date was early and accumulative mean temperature reached $95 \sim 115^{\circ} \mathrm{C}$ before continuous snow cover, frost damage of the seedlings was serious. On the other hand, when seeding date was as late as early to late December, seedlings emerged after overwintering at a high rate, and grew and matured normally. We consider that the suitable seeding date for winter-seeding cultivation in Iwate Prefecture is early to late December. The winter-seeded wheat was inferior to the nomal autumn-seeded wheat in top growth, but had a large number of ears, low lodging frequency and a high grain yield of $379 \mathrm{~g} / \mathrm{m}^{2}$, which was $95 \%$ of that in autumn-seeded wheat. The appearance quality of the grain was also nearly the same as that in autumn-seeded wheat, and the protein content of the grain was $14.4 \%$, which was 1.4 point (\%) higher than that in autumn-seeded wheat. The number of ears increased linearly with increasing seeding density. Grain yield also increased with increasing seeding density, but the maximum yield was 350 grains $/ \mathrm{m}^{2}$.

Key words : Seeding date, Seeding density, Wheat, Winter habit, Winter seeding.

\section{書 評}

「有用植物－ものと人間の文化史 119」菅洋著，法政大学出版局，東京，2004 年，313 頁，3200円.

作物学会の若い会員の中には星川清親著「新編食用作物」などの教科書に学んだ方も多いと思う。いつぽう工芸作物, 飼料作物, 果樹, 花卉, 蔬菜を含む広い範囲の作物に興味のある方は各種の植物図鑑や農学大事典などで勉強された かと思う。序章「有用植物とは何か」に示されているように，本書は教科書とも図鑑や事典とも違った本として執筆 が企画された。 とくに文化史，民族植物学を基盤にして人間の生活を主体に，科学史上興味あるエピソードを交え， できる限り一般の人でも興味を持って読んでいけるように工夫されている.

「メキシコの民族植物学」,「日本の民族植物学」,「多様な有用植物」,「世界の食糧植物」,「史前帰化植物」,「果実の 利用」, 「薬用植物」,「ハーブと香辛料植物」,「有用植物ア・ラ・カルト」と続き「二一世紀型の有用植物」で終章と なっている。ここで扱われている植物はイネ，トウモロコシ，コムギ，ダイズを始めとして，目次に現れる有用植物 だけでも 100 種類を超え，人類がいかに多くの植物を上手に利用してきたかが良く分かる.

評者の住む福島市特産のモモに関するページを開いてみると「ペルシャ方面へのアレキサンダー大王の遠征がこの 果実をもたらしたので，モモの学名にはペルシャを意味するペルシカが種名として与えられた。しかし，十九世紀に なってこの説に疑問が提出され，現在ではモモは中国起源だということが定着している.」とある。さらに，モモとア ーモンドの関係, 品種や栽培地に関する情報などが盛り込まれている. 同様に他の有用植物についてもその起源, 伝搬, 遺伝, 生理, 栽培, 加工, 利用や研究の現状などに関する興味深い知識が満載されている.

著者が意図したとおり，この本は確かに教科書ではなく，図鑑や事典でもなかった。私は一気に読んで「作物学の 分野で素晴らしい参考書が出版された.」と思いながらぺージを閉じた.

(東北農業研究センター 小柳敦史) 